\title{
Effect of Forchlorfenuron and N-Acetyl Thiazolidine 4-Carboxylic Acid on Size and Yield of Apricot (Prunus armeniaca L.) cv. New Castle
}

\author{
Debashish Hota*, D.P. Sharma, N. Sharma, Gopa Mishra, \\ Shivendu Pratap Singh Solanki and Vikramaditya Priyadarshi
}

\author{
Department of Fruit Science, Dr Y S Parmar University of Horticulture and Forestry, \\ Nauni, Solan, H.P., India \\ *Corresponding author
}

\section{A B S T R A C T}

\begin{tabular}{|c|}
\hline Keywords \\
\hline $\begin{array}{l}\text { Forchlorfenuron } \\
\text { (CPPU), N-acetyl } \\
\text { thiazolidine 4- } \\
\text { carboxylic acid } \\
\text { (NATCA), Foliar } \\
\text { Spray, Petal fall } \\
\text { stage. }\end{array}$ \\
\hline Article Info \\
\hline $\begin{array}{l}\text { Accepted: } \\
21 \text { August } 2017 \\
\text { Available Online: } \\
10 \text { September } 2017\end{array}$ \\
\hline
\end{tabular}

\section{Introduction}

Being the third important stone fruit crop next after peach and plum, in respect to area and production; apricot (Prunus armeniaca L.) still require an attention towards its increasing yield by decreasing the fruit drop and increasing the fruit size.

In Himachal Pradesh, apricot is being cultivated at an elevation of $900 \mathrm{~m}$ to $2000 \mathrm{~m}$ above mean sea level over an area of 3660 ha with an annual production of 4704 MT in 2014-15 (Anonymous, 2015).Leading growing districts are Solan, Shimla, Sirmour, Chamba, Kullu, Mandi, and Kinnaur.
A low-moderate chilling New Castle is the most commercial cultivar of apricot in the mid-hills of Himachal Pradesh. This cultivar ripens towards the third week of May when no other fruit is available and hence fetches higher prices in the market. However, with the advancement of age, its fruit size and quality decreases which has less demand in market. Many of the commercially available plant growth regulators are used in stone fruit production which enhance fruit size and quality and delay the storage disorder (Lurie, 2010).It is obvious that changes in the level of endogenous hormones due to biotic and 
abiotic stress alter the crop growth and any sort of manipulation including exogenous application of growth substances would help for yield improvement. Plant growth regulators provide effective means for the improvement of productivity as a result of direct influence on the qualitative as well as quantitative aspects of fruit growth (Taiz and Zeiger, 1998).

Forchlorfenuron, a synthetic cytokinin with strong growth regulation activities has been found very effective in enhancing fruit growth by stimulating cell division and cell elongation. It has been found highly effective in increasing fruit size in some fruit crops (Antognozzi et al., 1997; Cruz-Castillo et al., 2002).

Besides, it also modifies other fruit characteristics such as shape, dry matter content, carbohydrate metabolism and ripening process. Its treatment could also increase firmness of individual fruit, reducing TSS content and TSS /acid ratio of fruit, as well as, promote starch degradation but had no effect on titratable acid content (Nevine et al., 2016).

Elanta Super is an organic growth promoter which contains N Acetyl Thiazolidine 4Carboxylic Acid (NATCA), 10\% Folic acid with $0.2 \%$ adjuvant, used for plant growth increase in both fruit $\&$ production quality.It is a derivative of organic amino acid, which helps to develop fruits to its optimum level of size, shape, quality and taste. It is also useful for fruit setting, enhances quality, size, colour as well as taste and keeping quality of fruits. It is also a stabilizer buffer, to tolerate certain types of stresses more effectively (Berg, 1986).This study aimed to throw some light of the prospective on the use of CPPU and NATCA singly or in combinations to promote the yield quantitatively and qualitatively in New Castle Apricot.

\section{Materials and Methods}

The present investigations was carried out in the 26 years old apricot cv. New Castle planted in a spacing of $3 \times 3$ meter at experimental orchard of the Department of Fruit Science, Dr. Y.S. Parmar University of Horticulture and Forestry during the years 2015 and 2016.For the experiment, thirty trees were selected on the basis of uniform vigour and were maintained under uniform cultural practices during the entire course of investigation. The two bio-regulators i.e. CPPU (5 and 10 ppm), NATCA (50 and 100 ppm) and their combinations CPPU + NATCA $(5+50 \mathrm{ppm})$ are applied at two different stage i.e. pink bud and petal fall stage, while the untreated plant remain the control (Table 1).

Eleven treatment with three replication was setup with Randomized Block Design (RBD). For each treatment, 10 litres of spray solution was made. In order to decrease the surface tension of the droplets and facilitate absorption, a few drops of Teepol were added to the solution prior to spray.

The spray solutions of different plant growth regulators were applied on the trees with the help of foot sprayer to wet the developing buds and flower completely without causing runoff at morning hours without obstruction of wind drift.

The yield of fruits under different treatments was recorded at the time of harvest by weighing the total fruits on top pan balance. The yield was expressed in kilograms per tree $(\mathrm{kg} /$ plant $)$. The fruit size in terms of length and diameter of ten randomly selected fruits per replication was recorded with a digital Vernier Calliper (Model No. CD 6" CS). Fruit diameter was worked out by averaging the values of cheek and suture diameter which had been recorded separately. 
The average values of fruit length and diameter were expressed in millimetres $(\mathrm{mm})$.The ten selected fruits taken for recording the fruit size data were weighed on electronic top pan balance and the average fruit weight was expressed in gram per fruit ( $\mathrm{g} /$ fruit).The volume of fruits was measured by water displacement method. Ten selected fruits taken for measuring size and weight were immersed in a measuring cylinder filled with water up to a certain graduation. The difference between initial and final readings gave the measure of volume of fruit samples, which were averaged and expressed in cubic centimetre (cc) per fruit.

The data generated from these investigations were appropriately computed, tabulated and analyzed as described by Gomez and Gomez (1983) using MS-Excel, OPSTAT, SPAR1.0 and SPSS 16.0 by applying Randomized Block Design (RBD). The level of significance was tested for different variables at 5 per cent level of significance.

\section{Results and Discussion}

\section{Physico-chemical characteristics}

\section{Fruit size}

\section{Fruit length}

The data on average fruit size as affected by different treatments are shown in table 2 .

It is evident from the data that the fruit size measured in terms of fruit length was influenced by different the plant growth regulator treatments. During the year 2015, the maximum fruit length $(31.31 \mathrm{~mm})$ was observed in the treatment $\mathrm{T}_{4}(10 \mathrm{ppm}$ CPPU at petal fall), which was statistically at par with the treatments $\mathrm{T}_{8}(100 \mathrm{ppm}$ NATCA at petal fall), $\mathrm{T}_{3}$ (5 ppm CPPU at petal fall stage) and $\mathrm{T}_{10}(5 \mathrm{ppm}$ CPPU $+50 \mathrm{ppm}$ NATCA at petal fall). The minimum fruit length $(26.87 \mathrm{~mm})$ was recorded in control as compare to other treatments.

In the year 2016, the maximum fruit length $(28.45 \mathrm{~mm})$ was observed in the treatment $\mathrm{T}_{4}$ (10 ppm CPPU at petal fall), which was statistically similar to treatments $\mathrm{T}_{8}(100 \mathrm{ppm}$ NATCA at petal fall $), T_{3}(5 \mathrm{ppm}$ CPPU at petal fall stage $)$ and $\mathrm{T}_{10}(5 \mathrm{ppm}$ CPPU +50 ppm NATCA at petal fall).

The minimum fruit length $(24.49 \mathrm{~mm})$ was observed in control, which was statistically at par with the treatments $\mathrm{T}_{5}$ (50 ppm NATCA at pink bud), $\mathrm{T}_{6}$ (100 ppm NATCA at pink bud) and $\mathrm{T}_{9}(5 \mathrm{ppm}$ CPPU +50 ppm NATCA at pink bud).

\section{Fruit diameter}

It is apparent from the data presented in table 2 that plant growth regulator treatments significantly influenced the fruit size when measured in terms of fruit diameter, during both the years of study.

The perusal of data on fruit breadth for the year 2015 (Table 2) clearly reveals that fruits from trees treated with CPPU at $10 \mathrm{ppm}$ at petal fall stage $\left(\mathrm{T}_{4}\right)$ was found to be broadest $(31.64 \mathrm{~mm})$ as compare to all other treatments. In the similar context fruit diameter was found to be significantly lowest in the control (26.91).

In the year 2016, maximum fruit $(29.37 \mathrm{~mm})$ diameter was recorded in trees treated with CPPU at $10 \mathrm{ppm}$ at petal fall stage $\left(\mathrm{T}_{4}\right)$, which was however, statistically at par with the treatments $T_{8}(100 \mathrm{ppm}$ NATCA at petal fall), $\mathrm{T}_{3}(5 \mathrm{ppm}$ CPPU at petal fall stage) and $\mathrm{T}_{10}$ (5 ppm CPPU + $50 \mathrm{ppm}$ NATCA at petal fall). The fruit diameter was markedly lower in control $(24.49 \mathrm{~mm})$ in comparison to all other treatments. 


\section{Fruit weight}

The data pertaining to the effect of plant bioregulators on fruit weight are presented in table 2 .

It is evident from the data that the fruit weight was significantly increased by different plant growth regulator treatments. In the year 2015, the values of average fruit weight varied from 13.53 to $18.34 \mathrm{~g} /$ fruit. The maximum fruit weight $(18.34 \mathrm{~g} /$ fruit) was recorded in the treatment $\mathrm{T}_{4}(10 \mathrm{ppm}$ CPPU at petal fall), which was however, statistically at par with $\mathrm{T}_{10}(5 \mathrm{ppm}$ CPPU $+50 \mathrm{ppm}$ NATCA at petal fall)and $\mathrm{T}_{3}(5 \mathrm{ppm}$ CPPU at petal fall stage). The minimum fruit weight (13.53 g/fruit) was registered in control, which was however, statistically at par with $\mathrm{T}_{5}(50 \mathrm{ppm}$ NATCA at pink bud) and $\mathrm{T}_{6}$ (100 ppm NATCA at pink bud).

In the next year, the maximum fruit weight (14.06 g/fruit) was recorded in the treatment $\mathrm{T}_{4}$ (10 ppm CPPU at petal fall) which was closely followed by $\mathrm{T}_{8}(100 \mathrm{ppm}$ NATCA at petal fall), $\mathrm{T}_{3}$ (5 ppm CPPU at petal fall stage) and $\mathrm{T}_{10}(5 \mathrm{ppm}$ CPPU +50 ppm NATCA at petal fall), which were however, statistically at par with each other. The fruit weight was found to be lower in control (10.29 g/fruit) and was statistically similar with $\mathrm{T}_{5}(50 \mathrm{ppm}$ NATCA at pink bud) and $\mathrm{T}_{6}$ (100 ppm NATCA at pink bud).

\section{Fruit volume}

The perusal of data presented in table 2 reveals that the fruit volume was significantly influenced by the treatments of forchlorfenuron and $\mathrm{N}$-acetyl thiazolidine 4carboxylic acid during both the years of study.

In the year 2015, the values of fruit volume varied from 11.80 to $15.93 \mathrm{cc}$ under different treatments. The highest value $(15.93 \mathrm{cc})$ pertained to the treatment $\mathrm{T}_{4}(10 \mathrm{ppm}$ CPPU at petal fall), which was closely followed by $\mathrm{T}_{8}\left(100 \mathrm{ppm}\right.$ NATCA at petal fall) and $\mathrm{T}_{10}(5$ ppm CPPU + 50 ppm NATCA at petal fall); these treatments were however, statistically at par with each other, but significantly superior to control. The fruit volume $(11.80 \mathrm{cc})$ was recorded to be lowest in control $\left(\mathrm{T}_{11}\right)$ which was however, statistical at par with $\mathrm{T}_{6}(100$ ppm NATCA at pink bud).

In the year 2016, the fruit volume was found highest $(13.93 \mathrm{cc})$ in the treatment $\mathrm{T}_{4}(10 \mathrm{ppm}$ CPPU at petal fall). The $\mathrm{T}_{3}(5 \mathrm{ppm}$ CPPU at petal fall stage), $\mathrm{T}_{8}(100 \mathrm{ppm}$ NATCA at petal fall)and $\mathrm{T}_{10}(5 \mathrm{ppm}$ CPPU $+50 \mathrm{ppm}$ NATCA at petal fall) was the second best treatment in respect of this attribute, which was statistically similar with the highest value. The fruit volume was observed lowest (9.86 cc) in the control which was however, statistically at par with $\mathrm{T}_{5}(50 \mathrm{ppm}$ NATCA at pink bud).

\section{Fruit yield}

The data on the fruit yield as influenced by pre-harvest application of different plant growth regulators at pink bud and petal fall stage are presented in table 2.

In the year 2015, maximum yield (22.13 $\mathrm{kg} /$ plant) was obtained from the tree receiving 10 ppm CPPU at petal fall $\left(\mathrm{T}_{4}\right)$, which was however, statistically at par with $\mathrm{T}_{8}(100 \mathrm{ppm}$ NATCA at petal fall $)$ and $\mathrm{T}_{10}(5 \mathrm{ppm}$ CPPU and $100 \mathrm{ppm}$ NATCA at petal fall). The minimum yield was recorded in control $(15.87 \mathrm{~kg} /$ plant $)$ which was significantly lower than remaining treatments.

A significantly higher fruit yield (17.15 $\mathrm{kg} /$ tree) was recorded again in trees treated with CPPU at $10 \mathrm{ppm}$ at petal fall $\left(\mathrm{T}_{4}\right)$ which was statistically at par with $\mathrm{T}_{8}(100 \mathrm{ppm}$ NATCA at petal fall $)$ and $\mathrm{T}_{10}(5 \mathrm{ppm} \mathrm{CPPU}+$ 50 ppm NATCA at petal fall). 


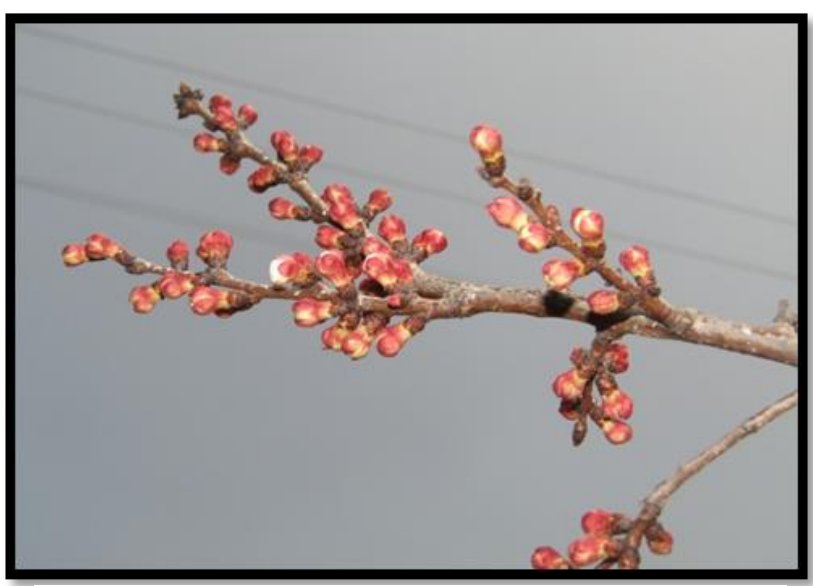

Pink Bud Stage

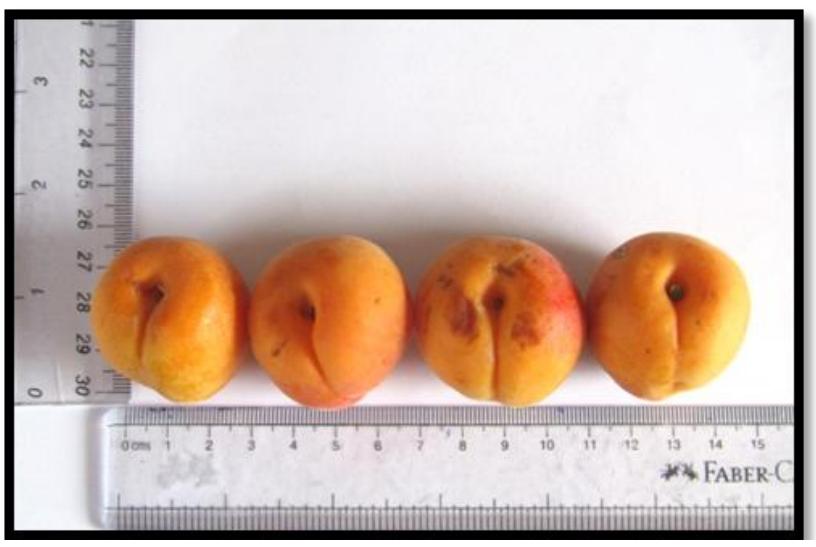

Effect of 10 ppm CPPU at petal fall stage

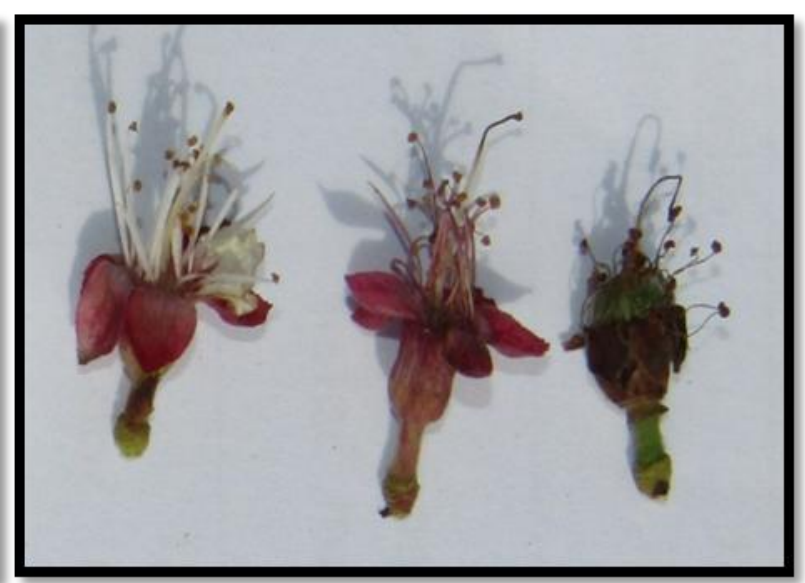

Petal Fall Stage

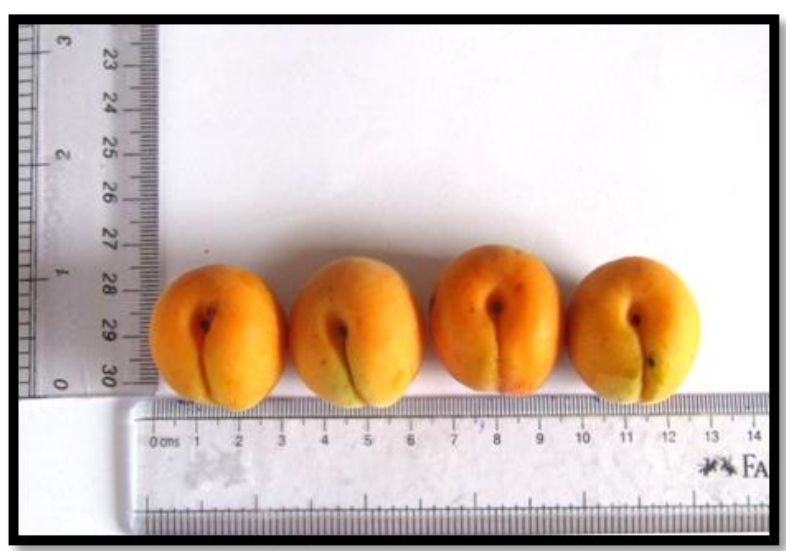

Control

Table.1 Description of application of forchlorfenuron (CPPU) and $\mathrm{N}$-acetyl thiazolidine 4-carboxylic acid

\begin{tabular}{|c|c|c|c|}
\hline Treatments & Chemicals & Concentration $\mathbf{( p p m )}$ & Time of application \\
\hline $\mathbf{T}_{\mathbf{1}}$ & CPPU & 5 & Pink bud \\
\hline $\mathbf{T}_{\mathbf{2}}$ & CPPU & 10 & Pink bud \\
\hline $\mathbf{T}_{\mathbf{3}}$ & CPPU & 5 & Petal fall \\
\hline $\mathbf{T}_{\mathbf{4}}$ & CPPU & 10 & Petal fall \\
\hline $\mathbf{T}_{\mathbf{5}}$ & N-ATCA & 50 & Pink bud \\
\hline $\mathbf{T}_{\mathbf{6}}$ & N-ATCA & 100 & Pink bud \\
\hline $\mathbf{T}_{\mathbf{7}}$ & N-ATCA & 50 & Petal fall \\
\hline $\mathbf{T}_{\mathbf{8}}$ & N-ATCA & 100 & Petal fall \\
\hline $\mathbf{T}_{\mathbf{9}}$ & CPPU + N-ATCA & $5+50$ & Pink bud \\
\hline $\mathbf{T}_{\mathbf{1 0}}$ & CPPU + N-ATCA & $5+50$ & Petal fall \\
\hline $\mathbf{T}_{\mathbf{1 1}}$ & CONTROL & & \\
\hline
\end{tabular}


Table.2 Effect of forchlorfenuron and $\mathrm{N}$-acetyl thiazolidine 4-carboxylic acid on fruit length, breadth, weight, volume and yield of apricotcv. New Castle

\begin{tabular}{|c|c|c|c|c|c|c|c|c|c|c|}
\hline \multirow[t]{2}{*}{ Treatments } & \multicolumn{2}{|c|}{$\begin{array}{c}\text { Fruit length } \\
(\mathrm{mm})\end{array}$} & \multicolumn{2}{|c|}{$\begin{array}{c}\text { Fruit diameter } \\
(\mathbf{m m})\end{array}$} & \multicolumn{2}{|c|}{$\begin{array}{c}\text { Fruit weight } \\
\text { (g) }\end{array}$} & \multicolumn{2}{|c|}{$\begin{array}{c}\text { Fruit volume } \\
\text { (cc) }\end{array}$} & \multicolumn{2}{|c|}{$\begin{array}{c}\text { Yield }(\mathrm{kg} / \\
\text { tree })\end{array}$} \\
\hline & 2015 & 2016 & 2015 & 2016 & 2015 & 2016 & 2015 & 2016 & 2015 & 2016 \\
\hline $\mathrm{T}_{1}$-CPPU (5 ppm) & 27.89 & 26.98 & 27.90 & 27.36 & 15.24 & 12.27 & 14.00 & 11.80 & 17.97 & 13.73 \\
\hline $\mathrm{T}_{2}$-CPPU (10 ppm) & 29.37 & 26.58 & 28.02 & 26.97 & 16.91 & 12.11 & 14.87 & 12.67 & 18.63 & 14.02 \\
\hline $\mathrm{T}_{3}-\mathrm{CPPU}(5 \mathrm{ppm})$ & 30.77 & 27.63 & 30.57 & 28.55 & 17.50 & 13.98 & 14.93 & 13.67 & 20.00 & 15.23 \\
\hline $\mathrm{T}_{4}-\mathrm{CPPU}(10 \mathrm{ppm})$ & 31.31 & 28.45 & 31.64 & 29.37 & 18.34 & 14.06 & 15.93 & 13.93 & 22.70 & 17.15 \\
\hline $\mathrm{T}_{5}$-NATCA (50 ppm) & 27.60 & 24.89 & 27.60 & 26.30 & 14.40 & 10.84 & 12.93 & 10.40 & 18.33 & 14.92 \\
\hline $\mathrm{T}_{6}$-NATCA (100 ppm) & 28.42 & 25.10 & 27.51 & 26.97 & 14.18 & 10.92 & 12.73 & 11.20 & 18.43 & 14.28 \\
\hline $\mathrm{T}_{7}$-NATCA $(50 \mathrm{ppm})$ & 29.04 & 26.43 & 29.62 & 27.53 & 15.20 & 13.00 & 14.93 & 12.67 & 19.23 & 15.72 \\
\hline $\mathrm{T}_{8}$-NATCA (100 ppm) & 30.79 & 27.59 & 30.15 & 28.72 & 17.43 & 13.48 & 15.00 & 13.33 & 21.53 & 16.73 \\
\hline $\mathrm{T}_{9}$-CPPU+NATCA(5+50 ppm) & 28.29 & 25.28 & 27.61 & 27.00 & 14.70 & 11.67 & 14.33 & 12.13 & 18.93 & 14.23 \\
\hline $\mathrm{T}_{10}$-CPPU+NATCA(5+50 ppm) & 30.69 & 27.63 & 30.67 & 28.71 & 17.92 & 13.56 & 15.80 & 13.27 & 21.20 & 16.08 \\
\hline $\mathrm{T}_{11}$-Control & 26.87 & 24.49 & 26.92 & 24.50 & 13.53 & 10.30 & 11.80 & 9.87 & 15.87 & 10.16 \\
\hline $\mathrm{CD}_{0.05}$ & 0.71 & 0.88 & 0.61 & 0.89 & 0.90 & 0.99 & 0.94 & 0.91 & 1.01 & 1.32 \\
\hline
\end{tabular}

However, fruit yield in untreated control was observed to be significantly lowest (10.16 $\mathrm{kg} /$ tree) during 2016.

The pooled data over the years revealed that tree receiving $10 \mathrm{ppm} \mathrm{CPPU}$ at petal fall stage gave highest yield (19.39 kg/tree) which was however, statistically similar with treatments $_{8}(100 \mathrm{ppm}$ NATCA at petal fall) and $\mathrm{T}_{10}(5 \mathrm{ppm}$ CPPU and 100 ppm NATCA at petal fall). The minimum yield was obtained from the untreated control plants $(13.01 \mathrm{~kg} /$ tree $)$.

In the present investigation, fruit size, weight and volume were markedly increased by the treatments of CPPU applied at 5-10 ppm and NATCA at 50-100 ppm. Both the chemicals has significantly affected the fruit size when applied at petal fall stage. The application at this stage may be related to the stimulus of ovule development, once the ovule produces endogenous hormones that help in fruit set and increase in size (Silva et al., 2010). It may also be due to accumulation of higher rates of auxin and cytokinin after the pollination and fertilisation, which act as an accelerator for increasing the size of fruit. While in contrast presence of growth inhibitor in dormant to semi-dormant (up to the induction of flower primordia) condition may inhibit the effect of exogenous application of growth regulator (Dhillon and Bhat, 2011).

The improvement in fruit quality grade obtained by the different bio-regulators might be due to increase in cell enlargement and carbohydrate sink strength (Dokoozlain, 2000), resulting in increasing fruit size and weight. CPPU has been shown to expand fruit size through cell expansion and division (Williamson and NeSmith, 2007).The increment in fruit size and weight with CPPU treatments might be due to the stimulation of cell division and elongation (Antognozzi et al., 1997). In this study, CPPU treatments increased the vegetative growth and leaf area (Tables 2 and 3), which might have resulted in greater availability of assimilate to the developing fruits. Furthermore, CPPU may directly cause increase in assimilate transfer towards the fruits by affecting the sink strength of treated fruits, which further causes increase in rate of assimilate transfer towards 
the fruits and it act as a sink (Patrick, 1988).Patterson et al., (1993) reported that CPPU stimulated cell expansion in the pericarp sufficiently to explain the measured increase in total fruit volume. Present findings confirm those of Guirguis et al., (2010) who mentioned that CPPU 10 ppm after twoweeks of full bloom on Costata persimmon, gave the highest yield $/ \mathrm{kg} /$ tree and heaviest, largest and mostfirm fruits. The present results concerning the effect of CPPU on the fruit dimensions are in harmony with those obtained by Flaishman et al., (2006) in pear, Kim et al., (2006) in kiwifruit, Scorza et al., (1991) in peach, Retamales et al., (2014) in blueberry, Kittiwatsopon and Karintanyakit (2016) in grape and Thakur (2014) in apricot cv. New Castle.

Elanta super is a biostimulant for crops, claimed to contain an amino acid L-cysteine and a vitamin folic acid. It is possible that the amino acids and vitamins in the Ergostim enabled the better utilization of higher levels of fertilizer resulting in better plant growth (Kulasegaram and Kathiravetpillai, 1982). Elanta super may increase the growth promoting substances as it contain rich amount of amino acid and folic acid. Foliar application of mixture of amino acids and algae suspension significantly increased the weight of bunches and the size of grape berries (Nagy and Pinter, 2015). The present results concerning the effect of NATCA on the fruit dimensions are in harmony with those obtained by Ramteke and Khot (2015) in grape, Ramteke et al., (2012) in grape, Dubravec et al., (1995) in apple.

In the present investigation, higher yield was obtained under the treatments of $10 \mathrm{ppm}$ CPPU and NATCA 100 ppm at petal fall stage. These results are well understandable as these treatments caused higher increase in fruit size and weight (Table 3). Similarly, higher yield was obtained by Marvet et al.,
(2001) in 'Thompson Seedless' grapevines, following the application of Sitofex (CPPU) when applied at 3, 5, $7 \mathrm{ppm}$ alone or in mixture with $\mathrm{GA}_{3}$ at $40 \mathrm{ppm}$. Stern et al., (2006) stated that the improving effect of Sitofex on fruit weight and dimensions, as well as on reducing pre-harvest fruit drop resulted in increased fruit yield in apple. These findings related to higher yield with CPPU are in agreement with those established by Faissaland Abdel (2007) in pear, Fathi et al., (2011) in persimmon and Raheem et al., (2013) in 'Washington Navel' orange. Thakur (2014) also found similar results by applying 10 ppm CPPU at petal fall stage in apricot cv. New Castlein regard to fruit yield.

\section{References}

Anonymous, 2015. Horticulture development in Himachal Pradesh at a glance, http://www.hphorticulture.nic.in.

Antognozzi, E., Famiani F and Proietti P. 1997. Effect of CPPU on fruit anatomical structure and quality of kiwifruit. Acta Horticulturae444 (2): 459-463

Berg, C.L., 1986. Farm chemical Handbook (ed). Meister publishing company, Willoughty, U.S.A. pp 10-16

Cruz-Castillo, J.G., Woolley DJ and Lowes GS.2002. Kiwifruitsize and CPPU response are influenced by the time of anthesis. Scientia Horticulturae 95: 2330

Dhillon, W.S., and Bhat ZA. 2011. Fruit tree Physiology. Narendra Publishing House, Delhi. p. 312

Dokoozlain, N.K., 2000. Plant growth regulator use for table grape production in California. Proceedings of the.4th International symposium. Tabel Grape Growers Council. pp. 129-143.

Dubravec, K., Dubravec I and Manitasevic J. 1995.The Effect of the Bioregulators Agrispon $^{\circledR}$ and Ergostim on the 
Vegetative and Reproductive Growth of Apples. Journal of sustainable agriculture 5(1/2): 45-48

Faissal, F.A., and Abdel AAM. 2007. Effect of concentrations and date of spraying Sitofex (CPPU) on yield and quality of Le-Conte pear fruits. African crop science conference proceedings 8: 523527

Fathi, M.A., Mohamed AI and Abd El-Bary A. 2011. Effect of CPPU and $\mathrm{GA}_{3}$ spray on fruit set, fruit quality, yield and monetary value of 'Costa' Persimmon. Nature and Science 9(8): 40-49

Flaishman, M.A., Shargal A, Shlizerman L and Stern RA. 2006. The synthetic cytokinins CPPU and TDZ prolong the phase of cell division in developing pear (Pyrus communis L.) fruit. Acta Horticulturae 671: 151-157

Gomez, K.A., and Gomez AA. 1983. Statistical procedures for agricultural Research. John Wiley and Sons Inc., New York. pp. 357-427

Guirguis, N.S., Eman S, Attala GB, Mikhael $S$ and Gaber MA. 2010. Effect of Sitofex quality of "Costata" of persimmon trees. J. Agric. Res. Kafer El-Shiekh Univ. 36(2): 251-256

Kim, J.G., Takami Y, Mizugami T, Beppu K, Fukuda $T$ and Kata I. 2006.CPPU application on size and quality of Hayward kiwifruit. Scientia Horticulturae 110(2): 219-222

Kittiwatsopon, K., and Karintanyakit P. 2016. Effect of gibberellic acid and forchlorfenuron (N-(2-chloro-4pyridyl)-N'-phenylurea) on growth and quality of 'Marroo Seedless' grape. Acta Horticulturae 1115: 225-230

Kulasegaram, S., and Kathiravetpillai A. 1982.Effect of sprays of the biostimulant ergostim on growth, recovery from pruning and yield of tea (Camellia sinensis L.). Tea 51(3): 127134
Lurie, S., 2010. Plant Growth Regulators for Improving Postharvest Stone Fruit Quality. Acta Horticulturae 884:189197.

Marvet, A.K., Ali A, Ibrahim H and Rizk IA. 2001. Effect of CPPU on yield and bunch quality of Thompson Seedless grapevines. Egyptian Journal of Agricultural Research 79(2): 531-550

Nagy, P.T., and Pinter T. 2015.Effects of Foliar Biofertilizer Sprays on Nutrient Uptake, Yield, and Quality Parameters of Blaufrankish (Vitis vinifera L.) Grapes. Communications in Soil Science and Plant Analysis 46(1):219227

Nevine, T.M., and Ghany KME. 2016. Some horticultural and pathological studies to reduce fruit decay of "Anna" apple and increase fruit set, yield and improve fruit quality and storability. Journal of American Science 12(1): 104-122

Patrick, J.W., 1988. Assimilate partitioning in relation to crop productivity. Horticultural Science 23: 33-40

Patterson, K.J., Mason KA and Gould KS. 1993. Effect of CPPU (N-(2-chloro-4pyrydil)-N'-Phenylurea) on fruit growth, maturity and storage quality of kiwifruit. New Zealand Journal of Crop and Horticultural Science 21: 253-261

Raheem El Abd, Rahman ME El Abd, Hoda GF, Mohamed $\mathrm{M}$ and Elharony SB. 2013.Regulation of Navel orange cropping and improvement of fruit quality using Sitofex and gibberellic acid. Nature and Science 11(6): 13-21

Ramteke, S.D., and Khot AP. 2015. Study in changes in physiological parameter and yield with application of NATCA (Elanta super), $\mathrm{GA}_{3}$ and $\mathrm{CPPU}$ in Sonaka Grapes. International Journal of Tropical Agriculture 33(2): 229-231

Ramteke, S.D., Somkuwar RG, Bhange MA, Kor RJ and Rajurkor AB. 2012. Impact of biostimulant (Fantac) on yield and 
self-life of Thompson Seedless grape. Annals of Plant Physiology, 26(1): 1517

Retamales, J.B., Godoy R, Moggia C, Lobos GA and Romero S. 2014. CPPU Sprays Alter Blueberry (Vaccinium corymbosum L. 'Duke') Fruit Quality at Harvest and Its Behavior in Postharvest. Acta Horticulturae, 1017:189-194

Scorza, R., May LG, Purnell B and Upchurch B. 1991. Differences in number and area of mesocarp cells between smalland large fruited peach cultivars.Journal of America Society of Horticultural Science, 116: 861-864

Silva, J.B., Neto AG, Pazzin D, Fachinello JC and Giacobbo CL. 2010. Fruit Set of Pear Fruits 'Garber' in the Different Fruiting Organs Regarding Quadrant, Pruning, Girdling, Bending and Chemical Treatments. Acta Horticulturae, 872: 289-294
Stern, R.A., Arie BR, Applebaum S and Flaishman M. 2006. Cytokinins increase fruit size of 'Delicious' and 'Golden Delicious' (Malus domestica) apple in a warm climate. Journal of Horticultural Science and Biotechnology, 81(1): 5156.

Taiz, L., and Zeiger E. 1998. Plant physiology (2 Ed.) Sunderland: Sinauer Associates, $793 \mathrm{p}$.

Thakur, K., 2014. Effect of forchlorfenuron, prohexadione-calcium and brassinolide on fruit yield, maturity and quality of apricot (Prunus armeniaca L.) cv. New Castle. Msc. Thesis. Dr. Y S Parmar University of Horticulture and Forestry, Nauni, Solan (H.P.).

Williamson, J.G., and NeSmith DS. 2007. Effects of CPPU applications on southern high bush blueberries. Horticultural Science, 42: 1612-1615

\section{How to cite this article:}

Debashish Hota, D.P. Sharma, N. Sharma, Gopa Mishra, Shivendu Pratap Singh Solanki and Vikramaditya Priyadarshi. 2017. Effect of Forchlorfenuron and N-Acetyl Thiazolidine 4Carboxylic Acid on Size and Yield of Apricot (Prunus armeniaca L.) cv. New Castle. Int.J.Curr.Microbiol.App.Sci. 6(9): 1852-1860. doi: https://doi.org/10.20546/ijcmas.2017.609.228 